\title{
«I mellemtiden har jeg lært alle den sociologiske forståelses sygdomme at kende.»
}

\author{
Interview af Pierre Bourdieu (1930-2003) ved Beate Krais
}

Beate Krais: Da du skrev denne bog, havde du allerede nogen erfaring med sociologisk forskning. På hvilket tidspunkt i dit arbejde fandt du det nyttigt eller nødvendigt at gennemføre den sociologiske refleksion, som kommer til udtryk i The Craft of Sociology? (Bourdieu et al., 1991) Jeg spørger dig, fordi du nu har meget mere erfaring ... og dog, allerede dengang havde du udført en hel del arbejde.

Pierre Bourdieu: Bogen begyndte at tage form i 1966. På det tidspunkt havde École des Hautes Études påbegyndt et intensivt uddannelsesprogram i sociologi. Jean-Claude Passeron og jeg havde undervist på et kursus i epistemologi, og at samle bogen var en måde at forevige kurset på uden at skulle gentage det hvert år. Så fra starten var der en didaktisk intention, og bogen blev præsenteret som en håndbog. Men på samme tid var der en større ambition: ved at skrive en håndbog, kunne vi skrive en fordringsløs afhandling om sociologisk metode.

B.K.: Men det var vel også en refleksion over, hvad der allerede var lavet?

P.B.: Ja, der var en didaktisk intention, men også et $\emptyset$ nske om at lave statusopg ørelse over ti års feltarbejde, først i etnologi og siden i sociologi. Jeg havde udført en masse arbejde i Algeriet med folk fra Algeriets statistiske institut, og jeg havde følelsen af, at jeg efterhånden brugte en metode, som ikke havde været ekspliciteret. Følelsen af, at det absolut skulle gøres eksplicit blev styrket af, at den 'lazarfeldske' invasion var på sit højeste i Frankrig. Paul F. Lazarsfeld - vi taler om 1960'erne - var kommet til Paris og havde holdt højtidelige lektioner ved Sorbonne, som alle de franske sociologer deltog i, undtagen mig. Jeg blev væk efter omtanke. Jeg tænkte, symbolsk, at jeg ikke behøvede at få lektioner i Lazarsfelds lære (jeg kunne bare nøjes med at læse hans bøger). Gennem nogle interessante teknikker, som det var nødvendigt at lære og som jeg havde lært, påtvang han derudover en implicit positivistisk epistemologi, som jeg ikke ønskede at acceptere. Og det var den

\footnotetext{
Teksten er en dansk utgave av teksten "Meanwhile, I have come to know all the diseases of sociological understanding" (Krais \& Bourdieu, 1991, (c) Walter de Gruyter \& Co, D-1000 Berlin). Oversettelsen (Krais \& Bourdieu, 1994, (C) Morten Nørholm og Karin Anna Petersen) publiseres med tillatelse fra forlaget Frydenlund. Oversetterne takker Frydenlund for tillatelsen til å publisere teksten her.
}

Publisert: 10.08 .2020

Praxeologi - Et kritisk refleksivt blikk på sosiale praktikker (C2020 Pierre Bourdieu \& Beate Krais 
virkelige baggrund for The Craft of Sociology. Faktisk er der en note i begyndelsen, som groft taget siger: Folk vil sige, at denne bog er skrevet mod empirisk sociologi, men det er ikke sandt. Den er designet til at give en teoretisk basis til en anden måde at lave empirisk forskning på ved at tilføje en teknik, som Lazarsfeld unægteligt har gjort meget for at fremme, med et andet epistemologisk udgangspunkt. Det var bogens egentlige intention. Dengang så jeg to modsatrettede vildfarelser, som sociologien måtte definere sig imod. Den første, som kunne kaldes teoreticistisk, var symboliseret med Frankfurterskolen, med andre ord folk, som uden at lave nogen empirisk forskning, så den positivistiske fare allevegne (Lucien Goldmann var den franske repræsentant for den retning). Den anden, s.om kunne kaldes positivistisk, var symboliseret ved Lazarsfeld. Det var Lazarsfeld/Theodore Adorno dyaden, om hvilken jeg har skrevet en note i Appendix til La Distinction (Bourdieu, 1979). Mod disse to tendenser $\emptyset$ nskede jeg at producere en empirisk sociologi, som var teoretisk funderet, en sociologi, som kunne have kritiske intentioner (som enhver videnskab), men som skulle udføres empirisk.

B.K.: Hvilke epistemologiske traditioner kunne du dengang trække på for at virkeliggøre den intention?

P.B.: På det tidspunkt var der først og fremmest min egen erfaring ... Jeg havde arbejdet i Algeriet med folk fra det statistiske institut, med alle mine venner fra INSEE, ${ }^{1}$ Alain Darbel, Claude Seibel, Jean-Paul Rivet, af hvem jeg lærte statistik "på jobbet". Det var virkelig et lykketræf. De tilhørte en meget regelret statistiktradition, der stod mål med den anglo-amerikanske, men som var ukendt for sociologer. De var på samme tid meget stringente med hensyn til sampling og matematiske modeller og låst fast i en bureaukratisk-positivistisk tradition, som forhindrede dem i at stille spørgsmål til elementær unders $\varnothing$ gelsespraksis. Kort $f ø r$ jeg skrev denne bog, underviste jeg i sociologi ved Ecole Nationale de la Statistique et des Études Économiques. Mens jeg underviste disse fremtidige statistikere, blev jeg klar over, at jeg var nødt til at undervise dem ikke alene i, hvordan man skulle behandle data, men også i hvordan man konstruerer objektet med henvisning til hvordan data var indsamlet. Ikke alene hvordan man skal kode, men også hvordan man skal udlede implikationerne af en kodning; ikke alene hvordan man skal skitsere et spørgeskema, men også hvordan man skal konstruere et sæt af spørgsmål på grundlag af en problematik, og så videre. Så dét var min erfaring.

Bortset fra det, havde jeg min uddannelse, og i kurserne i filosofi i min studietid havde jeg især været interesseret i videnskabsfilosofi, epistemologi og så videre. Til socialvidenskaben prøvede jeg, gennem Alexandre Koyré, at overføre en hel epistemologisk tradition, for eksempel repræsenteret ved Gaston Bachelard, Georges Canguilhem, Koyré, som ikke er særligt kendte udenlands, undtagen af folk som Thomas S. Kuhn - på den måde, at Kuhns teori om videnskabernes revolution ikke slog mig som en videnskabelig revolution ... Den tradition, som ikke nemt lader sig etikettere som en 'isme' har som gennemgående træk, at den forudsætter konstruktionen. Den fundamentale videnskabelige handling er konstruktionen af objektet; man nærmer sig ikke virkeligheden uden en hypotese, uden konstruktions-instrumenter. Og når man tror, man er fri af fordomme, konstruerer man stadig uden at vide det og i så tilfælde næsten altid inadækvat. I sociologiens tilfælde er denne opmærksomhed på konstruktion især nødvendig, fordi den sociale verden på en måde konstruerer sig selv. Vore hoveder er fulde af for-konstruktioner. I hverdagserfaringer såvel som i meget arbejde inden for socialvidenskaberne, anvender vores tænkning vidensinstrumenter, som tjener til at konstruere objektet, skønt de skulle forstås som objektet. Nogle af etnometodologerne opdagede dette omtrent på samme tid, men det lykkedes dem ikke at komme frem til ideen om det

\footnotetext{
${ }^{1}$ Institut national de la statistique et des études économiques.
} 
nødvendige brud, som det er påpeget af Bachelard. Det er derfor man ultimativt forbliver i den positivistiske tradition, når man definerer socalvidenskaberne så simpelt som 'resultat på resultat'. Dette kan ses tydeligt i dag med diskursanalyse som modefænomen (som har været enormt understreget af udviklingen af hjælperedskaber til registrering, som for eksempel video). Deres opmærksomhed på diskursen, taget for pålydende, som den præsenterer sig med en filosofi om videnskab som en registrering (snarere end en konstruktion), førte dem til at ignorere det sociale rum, inden for hvilket diskursen produceres, strukturerne, som determinerer den, opererer, og så videre.

B.K.: Ideen med konstruktionen af objektet ser ud til at være yderst vigtig. Nutildags er det måske banalt inden for naturvidenskaberne, men ingen kan sige, at det for socialvidenskabelige forskere er en del af værktøjet, som en forudsætning for enhver videnskabelig fremgangsmåde.

P.B.: Nødvendigheden af at bryde med for-konstruktionerne, forudopfattelserne, spontan teori, er specielt påtrængende i sociologi, fordi vores tænkning, vores sprog, er fuldt af for-konstruerede objekter, og jeg tror, at tre fjerdedel af al forskning ganske enkelt omdanner sociale sammenhænge til sociologiske sammenhænge. Der er utallige eksempler: Problemet alderdom, problemet kvinder, $\mathrm{i}$ det mindste når det er rejst på en bestemt måde, problemet ungdom ... Alle slags for-konstruerede objekter trænger sig på som videnskabelige objekter; med rødder i sund fornuft får de øjeblikkelig anerkendelse fra det videnskabelige samfund og en bredere offentlighed. For eksempel modsvarer en stor del af objektinddelingerne bureaukratiske inddelinger: Den st $\varnothing$ rste del af sociologien modsvarer inddelingen i ministerier, såsom undervisningsministeriet, kulturministeriet, sportsministeriet osv. Mere generelt er mange af de instrumenter, som anvendes i konstruktionen af den sociale virkelighed (såsom erhvervskategorier, aldersgrupper osv.), bureaukratiske kategorier, som ingen har tænkt igennem. Som Thomas Bernhard siger i Alte Meister (Bernhard, 1985): Vi er alle mere eller mindre "statens tjenere", funktionærer, eftersom vi er produkter af uddannelsessystemet, lærere ... Og for at bryde væk fra for-tænkte objekter skal man have en enorm energi, en billedstormende voldsomhed, som man oftere finder hos forfattere som Bernhard eller kunstnere som Hans Haacke end hos professorer i sociologi, uanset deres 'radikale' intentioner.

Problemet er, at disse for-konstruerede objekter synes at være selvindlysende, så et videnskabeligt arbejde, baseret på et brud med sund fornuft, støder ind $\mathrm{i}$ en mængde besværligheder. For eksempel bliver selv den mest elementære videnskabelige proces yderst vanskelig. Så længe du tager den, som du ser den, som den præsenterer sig selv, tilbyder den sociale verden færdiglavede data, statistikker, diskurser som nemt kan registreres osv. Kort sagt, når du spørger om det, den beder om at blive spurgt om, har den en stor del at sige for sig selv, den fortæller dig, hvad som helst du ønsker at vide, den giver dig tal ... Den kan lide sociologer, som registrerer, som genspejler, som fungerer som spejle. Positivisme er filosofien om videnskaben som et spejl ...

B.K.: Men er du ikke tæt på en positivistisk position, når du siger, at man ikke ved noget $\mathrm{i}$ sociologi, førend sociologen har samlet sine 'videnskabelige data' gennem videnskabeligt arbejde, ligesom inden for naturvidenskaberne? Jeg kan forstå, at inden for socialvidenskaberne kan man ikke tage tingene som 'sociale fakta', som de præsenterer sig selv. Men man må indrømme agenterne, at de er eksperter på deres eget liv, at de er klar over og har en praktisk viden om den sociale verden, og at denne praktiske viden er mere end en simpel illusion. 
P.B.: Blandt de for-konstruktioner, som videnskaben må sætte spørgsmålstegn ved, er der en bestemt idé om videnskab. På den ene side er der sund fornuft, som skal mistænkeliggøres, fordi sociale agenter ikke har medfødt visdom, la science infuse, som vi siger på fransk. En af forhindringerne for videnskabelig viden - jeg tror Émile Durkheim havde ret i at sige sådan - er illusionen om umiddelbar viden. Men på den anden side er det sandt, at overbevisningen om, at det er nødvendigt at konstruere mod sund fornuft, så igen kan begunstige en videnskabelig illusion, illusionen om absolut viden. Denne illusion er meget tydeligt udtrykt i Durkheims tilgang: Agenterne tager fejl, hvilket er et tab; berøvet en viden om helheden, har de en førstehånds, fuldstændig naiv viden. Så kommer videnskabsmanden, som begriber det hele og er en slags Gud sammenlignet med de almindelige $d \varnothing$ delige, som ingenting forstår. Sociologiens sociologi, som for mig er en integreret del af sociologien, er tvingende nødvendig for at sætte spørgsmålstegn ved såvel illusionen om absolut viden, som er uadskillelig fra videnskabsmandens position, og den specielle form, som denne illusion antager, afhængig af den position, som videnskabsmanden indtager i den videnskabelige produktions rum. Jeg har understreget dette synspunkt i Homo Academicus (Bourdieu, 1984). I forbindelse med studier af den akademiske verden, er risikoen særligt stor. Videnskabelig objektivering kan være at sætte sig selv i en position som Gudfader over for ens konkurrenter. Det var måske det første, jeg opdagede i mit etnologiske arbejde: Der er ting, du ikke længere forstår førend du tager den videnskabelige position i sig selv som objekt. Det faktum ikke at forstå sig selv som videnskabsmand, ikke at vide, hvad rollen som observat $\varnothing r$, som analytiker, indebærer, genererer fejl. Strukturalismen for eksempel - som jeg har forsøgt at vise i Le sens pratique (Bourdieu, 1980) - er baseret på illusionen om at placere de tanker som videnskabsmanden udarbejder om dem inde $\mathrm{i}$ agenternes hoveder.

B.K.: Der var Adorno/Lazarsfeld dyaden, som repræsenterede sociologiens Scylla og Charybdis. Men du hentydede også til sociologisk humanisme i The Craft of Sociology, og jeg spekulerer på hvad denne humanisme, som du præsenterede som en af farerne i sociologien, er eller var.

P.B.: Empirisk sociologi opstod delvis efter krigen i Frankrig, hos folk som var knyttet til de kristne venstreorienterede, sociale bevægelser (for eksempel var der Pere Lebret, som ledte en bevægelse kaldet Économie et Humanisme). De udførte, hvad man kunne kalde ... velgørenhedssociologi. Meget velmenende folk, som $\emptyset$ nskede at gøre godt i verden ... Der er en berømt bemærkning af André Gide, at "gode intentioner giver dårlig litteratur"; man kunne på tilsvarende måde sige, at gode intentioner giver dårlig sociologi. Efter min mening førte hele den kristen-humanistiske eller humanitærsocialistiske bevægelse sociologien ind i en blindgyde.

B.K.: Men den humanisme er måske ikke nødvendigvis kristen? Man kan se paralleller i visse venstreorienterede sociologier in spe, det kan være en sociologi inspireret af et ideal om socialt arbejde - i virkeligheden er det en vigtig tråd i angelsaksisk sociologi, man behøver bare at tænke på the Webbs (Beatrice og Sidney Webb) - eller en sociologi, som ønsker, at sociologer skal drive deres forskning ud fra et Klassenstandpunkt, som proletariatets st $\varnothing$ tte.

P.B.: Ulykkeligvis blev den empiriske sociologi om fritid, arbejde eller byer udført af folk, som var yderst humane, men, hvis jeg må sige det sådan, alt for humane ... Bruddet gælder også alt dette. Man bedriver ikke sociologi for at glæde sig over at lide med dem, der lider. Man må have modet til at sige nej til alt dette. Jeg kan huske, da jeg arbejdede i Algeriet midt under krigen, omgivet af ting, som berørte mig dybt, da prøvede jeg at holde en distance, som også var en måde at respektere folks værdighed på ... Den model, som jeg kommer til at tænke på her, er Gustave Flaubert, én der ser på 
virkeligheden med et distanceret blik, som ser ting med sympati, men uden at lade sig fange af det. Det er sandsynligvis derfor, jeg har været til irritation for mange mennesker; jeg har undslået mig préchi-précha, som vi siger på fransk, gode intentioner, menneskelig imødekommenhed. Et eksempel på denne holdning kan være min brug af ideen om interesser. Jeg bruger helt indlysende ikke ordet interesser i Jeremy Benthams betydning. Det har jeg brugt en masse tid på at forklare. Men det var en måde at bryde med den form for humanisme på, at gøre opmærksom på, at selv humanisten glæder sig over at kalde sig humanist.

B.K.: OK, men når du har dette kritiske blik, forudsætter du, at agenterne er medskyldige i det, som foregår. Ellers må du opfatte agenterne som marionetter, hvis snore bliver trukket af sociale strukturer helt uden for dem, såsom kapitalisme ...

P.B.: Sociologi er en meget vanskelig videnskab. Man bevæger sig hele tiden mellem to modsatrettede farer, man kan nemt komme fra asken og i ilden. Det er derfor, jeg har brugt mit liv på at nedbryde dualismer. Et af de punkter, jeg vil understrege stærkere end jeg gjorde i The Craft of Sociology, er behovet for at bevæge sig ud over parvise modsætninger, der ofte udtrykkes gennem begreber, som slutter på -isme. For eksempel har man på den ene side humanisme, som i det mindste har den fordel, at den opfordrer én til at bevæge sig nærmere til folk. Men det er ikke virkelige mennesker. På den anden side, har man teoreticister, som er millioner af mil væk fra virkeligheden og fra folk, som de er. Althusserianerne var typisk af den mening. Disse normaliens, ofte fra borgerskabet, som aldrig havde set en arbejder, en bonde, eller noget som helst, producerede en storslået teori uden agenter. Den teoreticistiske bølge kom netop efter The Craft of Sociology var publiceret. I enhver tidsperiode ville det være nødvendigt at skrive The Craft of Sociology forskelligt. Epistemologiske propositioner er udledt af refleksioner over videnskabelig praksis - en refleksion, som altid er underkastet de risici som er i højsædet på det pågældende tidspunkt. Ligesom den principielle risiko med tiden forandres, således må også den diskurs man lægger vægt på forandres. På det tidspunkt hvor The Craft of Sociology blev skrevet, var det nødvendigt at understrege den teoretiske retning imod positivismen. I 1970'erne, da den 'althusserianske' bølge skyllede hen over Frankrig, ville jeg have ønsket at understrege den empiriske retning over for den teoreticistiske, som reducerer agenterne til at være Träger, "bærere", af strukturerne. Ét aspekt af mit arbejde, for eksempel The Logic of Practice, er radikalt modstillet denne etnocentrisme udøvet af videnskabsmænd, der påberåber sig at kende sandheden om folk bedre end disse folk selv, og at være i stand til at gøre dem lykkelige på trods af dem selv, i overensstemmelse med den gamle platoniske myte om filosofkongen (moderniseret i form af kulten omkring Vladimir I. Lenin). Ideer som dem om habitus, praktik osv. blev udviklet, blandt andet for at påpege, at der er en praktisk viden, som har sin egen logik, der ikke kan reduceres til den teoretiske videns logik; at agenterne, på en måde, kender den sociale verden bedre end teoretikerne. Og på samme tid, sagde jeg også, naturligvis, at de ikke virkeligt kender den, og at videnskabsmandens arbejde består i at gøre denne praktiske viden eksplicit, i overensstemmelse med dens egne udtryksformer.

B.K.: Teoretisk eller videnskabelig viden er altså ikke totalt forskellig fra praktisk viden, fordi den er konstrueret som praktisk viden, men konstrueret eksplicit: Den rekonstruerer praktisk viden på en eksplicit måde og således "løfter den til bevidsthed", som man siger på tysk. På samme tid, må man huske på, er det, som er rekonstrueret med videnskaben som middel, den samme "ting", det er ikke et "objekt", eller en realitet, som tilhører en anden verden, uopnåelig for agenterne ... Men hvordan fungerer objekt-konstruktionen? Hvordan udføres den, hvordan opnår man den nødvendige distance uden umiddelbart at hæve sig op over de stakkels agenter, der "ikke ved, hvad de gør"? 
P.B.: Jeg tror mere end nogensinde, at det væsentligste er at konstruere objektet ... Gennem hele mit arbejde har jeg set, hvordan alting, inklusive tekniske problemer, er afhængig af den forberedende definition af objektet. Det er selvindlysende, at denne objekt-konstruktion ikke er en slags forudgående handling, og det at konstruere objektet ikke er det samme som at skitsere et "forskningsprojekt". Man kunne med udbytte lave en sociologi om de "forskningsforslag", som sociologer i De Forenede Stater skal skitsere for at få bevillinger. Man må på forhånd definere sine mål og metoder for at bevise, at det man vil lave er nyt set i forhold til tidligere arbejde og så videre. Den retorik, som skal mobiliseres for at udvikle den "metodologiske appel", som Adam Przeworski og Frank Salomon henviser til i deres håndbog for begyndere (Przeworski \& Salomon, 1981), indeholder en implicit, socialt sanktioneret epistemologi. Dette gælder i så høj grad, at hvis empirisk forskning ikke præsenterer sig i overensstemmelse med denne retoriks normer, har mange sociologer i USA og andre steder indtryk af, at det ikke er videnskabeligt. Hvorimod det i virkeligheden forholder sig sådan, at den måde et videnskabelig objekt præsenteres på, er nøjagtig det modsatte af logikken omkring arbejdet med at konstruere et objekt, et arbejde som ikke er gjort én gang for alle $\mathrm{i}$ begyndelsen, men som skal udføres i hvert eneste forskningsøjeblik, gennem en lang række af små korrektioner. Alt dette betyder ikke, at man møder objektet fuldstændig afvæbnet. Man har nogle generelle metodiske principper, som i en vis forstand er indskrevet i den videnskabelige habitus. Sociologens métier er netop dette - en teori om sociologiens konstruktion af objektet, omsat til en habitus. Når man behersker denne métier, behersker man på en praktisk måde alt, som er omfattet i de grundlæggende begreber: habitus, felt osv. Det betyder for eksempel, at for at have en chance for at kunne konstruere objektet, må man eksplicitere sine præsuppositioner for sociologisk at konstruere objektets for-konstruktioner; eller det betyder, at virkeligheden er relationel, at det, der eksisterer, er forhold, noget man ikke kan se, i modsætning til enkeltpersoner og grupper. Lad os tage et eksempel. Forestil dig, at jeg som projekt skal studere grandes écoles. Lige fra starten har jeg allerede lavet et afgørende valg ved at sige grandes écoles ... Hvert år er der en amerikaner, som kommer over for at studere École Polytechnique fra oprindelse til nutiden, eller en anden, som $\emptyset$ nsker at studere École Normale ... Alle og enhver finder dette ganske fornuftigt. En meget håndterbar opgave - objekterne er allerede ordnet, arkiverne let tilgængelige osv. Efter min mening skønt det vil tage tid at forklare dette detaljeret - kan man i virkeligheden ikke studere École Polytechnique isoleret fra École Normale og École Nationale d'Administration, de er placeret i ét rum. Så disse folk studerer et objekt, som overhovedet ikke er noget objekt. Og her vender vi tilbage til det, jeg sagde for et øjeblik siden: Desto mere naivt et objekt du studerer, jo nemmere præsenterer data sig, så de kan studeres. På den anden side: Så snart jeg siger, at det konstruerede objekt er hele gruppen af grandes écoles, løber jeg ind i utallige problemer - usammenlignelige statistikker f.eks. Og jeg er udsat for at blive betragtet som mindre videnskabelig end dem, der holder sig til de tilsyneladende objekter, fordi der er så store besværligheder, som må overvindes for at kunne håndtere det konstruerede objekt empirisk.

B.K.: Jeg kunne tænke mig at spørge dig om det andet bind af The Craft of Sociology. Hvorfor blev det ikke skrevet? I forordet til den anden franske udgave siger du, at der skulle have været tre bind de indledende epistemologiske overvejelser, som er den foreliggende bog, en anden bog om at konstruere objektet og en tredje, som skulle indeholde en kritisk fortegnelse over redskaber. Jeg kan sagtens forestille mig det tredje bind, men jeg har svært ved at forestille mig, hvordan en bog om at konstruere det sociologiske objekt ville se ud. 
P.B.: Det første bind skulle være en original bog, camoufleret som en håndbog, fordi der ikke fandtes andet om det emne; og jeg tror, at der selv i dag ikke er meget ... Med den anden del, blev det hele meget vanskeligere. Enten skulle vi samle tekster til en klassisk håndbog, bruge de overskrifter, som du forventer at finde i en sociologisk begynderbog (struktur, funktion, handlen etc.), eller vi ville gøre det samme som i den første del; det vil sige skrive en original afhandling, som ville have været en generel teori. Personligt havde jeg intet ønske om at producere en traditionel håndbog og tage stilling til spørgsmålet om "funktion og funktionalisme". Det ville have været en ren skolastisk $\emptyset$ velse. Den tredje del, om sociologens redskaber, kunne have været meget nyttig, men det ville have været det samme som at anerkende den teoretiske/empiriske opdeling, som svarer til den katastrofale modsætning mellem teori og metode i den angelsaksiske tradition. Vi sagde i The Craft of Sociology, at de forskellige statistiske teknikker indeholder implicit sociale filosofier, som skal ekspliciteres. Når man udfører en regressionsanalyse, en stianalyse, eller en faktoranalyse, har man brug for at vide, hvilken socialfilosofi, man bringer med, og især hvilken filosofi om kausalitet, handling, de sociale tings måder at eksistere på, man bringer med. Man vælger én teknik fremfor en anden på grundlag af et problem og den specielle objektkonstruktion. For eksempel har jeg gjort stor brug af korrespondanceanalyse, fordi jeg mener det er en væsentlig relationel teknik, hvis filosofi fuldstændigt stemmer med, hvad social virkelighed efter min mening er. Det er en teknik, som "tænker" i termer af relationer, som jeg forsøger at tænke ideen om felt. Så man kan ikke adskille objekt-konstruktion fra objekt-konstruktionens instrumenter, fordi man har brug for instrumenter, for at flytte sig fra et forskningsprogram til et videnskabeligt arbejde, og disse instrumenter er mere eller mindre anvendelige afhængig af, hvad du leder efter. Hvis jeg havde $\emptyset$ nsket at forklare de faktorer, som bestemmer studenternes forskellige succes i de forskellige skoler, da - under forudsætning af at jeg havde været i stand til at bevise uafhængigheden af de forskellige grundlæggende variable, hvilket efter min mening ikke lader sig gøre - kunne jeg have gjort brug af multipel regressionsanalyse.

B.K.: Så kommer vi tilbage til problemet om konstruktionen af objektet, denne gang i forbindelse med de instrumenter, som skal være tilpasset de specifikke objekter. Hvis jeg har forstået det rigtigt, er sociologens arbejde stort set bestemt af det specifikke objekts egenskab, dets historie ...

P.B.: Det er problemet med objektets særegenhed. Efter min forestilling om videnskabeligt arbejde, er det klart, at jeg kun kan arbejde med et kontekstbundet, tidsfæstet objekt. Lad os sige at jeg $\emptyset$ nsker at studere, hvordan professoralt sk $\varnothing n$ virker. Jeg antager, at den bed $\varnothing$ mmelse, som lærerne laver af deres elever og deres arbejde, er produktet af gennemført inkorporering af intellektuelle strukturer, som for eksempel opdelingen i discipliner. For at løse dette meget generelle problem, arbejder jeg med dem som har bestået Concours général's centrale prøve eller med de elevoptegnelser, som en bestemt lærer har bevaret fra 1960'erne, og præsenterer de kategorier, der er indeholdt i dem. Hvis jeg publicerer dette i dag, vil folk sige: "Disse data er forældede, alt dette er overstået, humanistiske lærere er ikke længere dominerende, nu er det matematiklærerne" osv. I virkeligheden er mit objekt de mentale strukturer hos en person, som har en af de mest inflydelsesrige sociale positioner i samfundet, som har magten til symbolsk at fordømme (du er dum eller værdiløs) eller indvie (du er intelligent). Det er et meget vigtigt objekt, som kan observeres alle vegne. Gennem mine analyser af en historisk situation, tilbyder jeg et program for andre empiriske analyser, som er udført i situationer forskellige fra den, jeg har studeret. Det er en invitation til en udviklende læsning og til en teoretisk induktion, som generaliserer ud fra en velkonstrueret speciel sag. Når man har lavet et program på denne måde (det er et spørgsmål om at eksplicitere mentale strukturer, principper for klassifikation, taxonomier som meget sandsynligt bliver udtrykt som adjektiver), skal man bare gentage undersøgelsen på et andet tidspunkt og på et andet sted og se 
efter det invariante. De, der kritiserer den "franske" måde i mine undersøgelsesresultater, undlader at se det, som er vigtigt, hvilket ikke er resultaterne, men den proces, gennem hvilken de er fundet. 'Teorier ' er forskningsprogrammer, som ikke efterlyser "teoretiske diskussioner", men praktiske implementeringer, som modbeviser eller generaliserer. Edmund Husserl plejede at sige, at man må fordybe sig i den enkelte sag, for at opdage det invariante i den; og Koyré, som havde deltaget i Husserls lektioner, viser at Galileo Galilei ikke behøvede at gentage eksperimentet om legemers bevægelse på jorden tusind gange for at forstå fænomenet om det frie fald. Han måtte simpelthen konstruere modellen imod det tilsyneladende. Når den specielle situation er godt konstrueret, holder den op med at være speciel, og normalt burde alle og enhver være i stand til at få det til at fungere.

B.K.: Tyve år er gået siden den første franske udgave af The Craft of Sociology udkom, og i de to årtier har sociologien udviklet sig betragteligt. I særdeleshed har den udviklet sig, hvad angår empirisk forskning; og du har også lavet en masse yderligere arbejde. Du har langt mere erfaring nu. Hvis du skulle skrive The Craft of Sociology om nu, hvad ville du da forandre? Kunne du ønske at tilføje noget?

P.B.: Fremfor alt ville jeg skrive det anderledes. Det er en programmatisk tekst. Jeg havde nogen erfaring bag mig, men fremfor alt havde jeg brug for at udtrykke min utilfredshed med den officielle diskurs om videnskabelig praktik. Nu forstår jeg bedre og mere praktisk, hvad der dengang blev fremsat som en programerklæring. I bund og grund vedbliver The Craft ofSociology med at være en bog af en lærer. Og der er en mængde negative ting i den, som er typiske for en lærer: Gør ikke dette eller hint ... Den er fuld af advarsler. Den er både programmatisk og negativ. Det er nærmest, som om man tilbød en grammatikhåndbog som en måde at lære folk at tale på ... På trods af at Le Métier de sociologue henviser til métier i den franske betydning (avoir du métier som betyder at have en "habitus", en praktisk beherskelse), præsenterer den en didaktisk diskurs, som derfor på en måde er latterlig. Den bliver ved med at gentage, at man skal konstruere, men uden nogen sinde at vise praktisk, hvordan man konstruerer. Jeg tror det er en bog, som også har forvoldt nogen skade. Den fik vækket folk, men den blev øjeblikkelig brugt i en teoreticistisk mening. En af de mange måder ikke at bedrive sociologi på er at beruse sig med velklingende ord og bringe endeløse ofre til de "indledende epistemologiske overvejelser". Métier'en er stort set overført gennem praktik, og for at være i stand til at overføre det, må man have internaliseret det meget dybtgående. Jeg siger ofte i mine seminarer, at jeg snarere er som en gammel læge, der kender alle den sociologiske forståelses sygdomme. Der er tilbøjeligheder til fejltagelser, som varierer afhængig af $k \emptyset n$, social oprindelse og intellektuel baggrund. Mandlige studenter er som oftest mere teoreticistiske, hvorimod kvindelige studenter er socialt disponeret til at være for beskedne, for tilbageholdende, for pertentlige, de søger tilflugt i empiriske detaljer, småting, og de har brug for at blive opmuntret til at være mere dristige, have mere teoretisk chutzpah ... Men disse dispositioner i sig selv varierer afhængig af social oprindelse: Teoretisk arrogance er mindre sandsynlig blandt første-generations intellektuelle ... Efter at have sagt det, er der en hel serie af klassiske sygdomme, som man kan genkende. Min erfaring som forskningsvejleder, til hvilken jeg kan tilføje erfaringen med alle de sygdomme, jeg selv har haft på et eller andet tidspunkt i min karriere, og alle de fejl, jeg har lavet, gør det muligt for mig, tror jeg, at undervise i principperne om objekt-konstruktion i praksis, som en gammel fagmand. Og dét er den store forskel fra det, som man finder i The Craft of Sociology. Hvis jeg skulle skrive denne bog igen, ville jeg præsentere en serie af eksempler, eller "svendestykker", som middelalderens fagmænd gjorde det. Som et eksempel på objekt-konstruktion, ville jeg give det, som er tilgængeligt $\mathrm{i}$ appendikset til Homo Academicus: Analysen af listen af "fremstående forfattere". Jeg ville sige: "Her er materialet, foran jer; det er tilgængeligt for enhver. Hvorfor er det dårligt konstrueret? Hvad 
betyder dette spørgeskema? Hvad ville du gøre ved det?" Det andet er et appendiks til Distinction, kaldet "Associations". En dag faldt jeg over et nummer af tidskriftet Sondages, publiceret af meningsmålingsorganisationen IFOP, som viste statistiske tabeller over fordelingen af de forskellige egenskaber, som respondenter havde tilskrevet et antal politikere (Giscard d'Estaing, Georges Marchais, Jacques Chirac, Servan-Schreiber etc.). Kommentarerne var begrænset til simple omskrivninger: Marchais er sammenlignet med fyrretræet osv. Man kunne give råmaterialet (Sondages' artikel) til studenterne og så, som en øvelse, spørge dem om, hvad de kunne få ud af det, og bagefter vise dem, hvad man kan få ud af det. I begge tilfælde er det et spørgsmål om at fremkalde de skjulte betingelser for konstruktionen af det for-konstruerede objekt, som ligger til grund for de naivt præsenterede resultater. I det første tilfælde må man sætte spørgmålstegn ved udvalget: Hvem er de sagkyndige, hvis bedømmelse fører til denne liste af bedste forfattere? Hvordan blev de udvalgt? Er forfattergruppen ikke allerede givet med fortegnelsen over de valgte sagkyndige og i deres opfattelseskategoriseringer? I det andet tilfælde, må man sætte spørgsmålstegn ved spørgeskemaet (i virkeligheden skal der altid sættes spørgsmålstegn ved spørgeskemaer ...). De folk, som stiller spørgsmålene, lægger ubevidste tankekategorier (som for eksempel: Fyr er mørk, dyster, træet bruges til kister, associerer med død osv.) i dem, og de får på denne måde respondenterne til at tilføje tilsvarende ubevidste kategorier, som viser sig stort set at være de samme. Det er kommunikation mellem ubevidstheder. Og på den måde kan en idiotisk unders $\varnothing$ gelse uden videnskabelig værdi tilvejebringe et fascinerende videnskabeligt objekt, hvis man i stedet for at tage resultaterne for pålydende, læser de tankekategorier projiceret i resultaterne, som de producerede. I begge tilfælde har man at gøre med allerede publicerede resultater, som trænger til at blive rekonstrueret. Det er ofte det, som sker. Med andre ord ville jeg give tre eller fire eksempler på ekstreme tilfælde, hvor det kun er ved at udføre i praksis, det som siges teoretisk i The Craft of Sociology, at man får et objekt snarere end en simpel artefakt, eller overhovedet ingenting. Jeg ville præsentere eksempler på empirisk arbejde med nogle kommentarer.

En anden ting, som jeg ville understrege, er sociologien om sociologi. Det er nævnt i slutningen, men meget abstrakt. Siden da er den del udviklet meget, især med Homo Academicus. Men bortset fra det, ville den store forskel ligge i måden at udtrykke tingene ... Jeg har ikke genlæst den ... men jeg tror, at mange ting i den ville irritere mig nu ... Jeg er sikker på, at jeg ville sige: Dette er så arrogant! Når du er ung, er du arrogant, på grund af usikkerhed ...

B.K.: Jeg begyndte med at bede dig om at placere The Craft of Sociology i sammenhængen for tyve år siden. Hvis du skulle skrive en ny The Craft of Sociology nu, hvad ville da blive sammenhængen? Hvilken debat ville bogen indgå i? Og hvilke specifikke problemer eller barrierer er opstået gennem de to årtiers arbejde og forskning?

P.B.: De væsentlige træk ved landskabet har ikke ændret sig

synderligt. Det "positivistiske" paradigme er stadig meget stærkt. Folk laver stadig empirisk forskning uden teoretisk forestilling med problemer, som i langt højere grad er et produkt af "videnskabelig" sund fornuft end ægte teoretisk refleksion; på den anden side er der universel teori, eviggyldig universel teori, fuldstændig løsrevet fra empirisk forskning. Kendsgerningen er, at de to går meget godt sammen; med andre ord kan man fortsætte med empirisk forskning af den positivistiske slags, mens man producerer teoretisk teori. Det, der nu om dage kaldes teori, er ofte kommentarer til kanoniske forfattere (i Tyskland, Storbritannien og USA er der en række "altfavnende teorier" modelleret efter Talcott Parsons) eller store trend-rapporter, der er produceret til undervisningsformål (ofte baseret på studenters noter). Tilfældigvis har jeg to ideal-typiske 
eksempler liggende på mit bord: En artikel af Robert Wuthnow og Marsha Witten, der bærer titlen: "New Directions in the Study of Culture" (Witten \& Wuthnow, 1988) og en af Judith R. Blau: "Study of the Arts; A Reappraisal" (Blau, 1988). Den teoretiske teoris status er sandsynligvis forklaret gennem det faktum, at disse forskelligartede og substansløse produkter af en slags akademisk hurtiglæsning, som ofte er forbundet med anvendelsen af tilsvarende absurde, akademiske kategorier til klassifikation, har en hjernevaskende funktion. Over for den teori, forstået som en specialitet i sin egen ret, er der "metodelære", serierne af opskrifter eller forskrifter, som man skal respektere, ikke for at kende objektet, men for at blive anerkendt som én, der kender objektet.

Når det er sagt, har situationen forandret sig meget, og jeg ville skrive helt anderledes ... Jeg tror, at en stor del af dem, der producerer sociologi i USA, har løsrevet sig fra det positivistiske paradigme. Der har været bevægelser som interaktionisme og etnometodologi, som har haft gavnlige virkninger, og de har sagt ting som er meget tæt på det, der siges i The Craft of Sociology (for eksempel, med deres refleksion over forudsætninger, folke-teorier osv.). Der har også været udviklingen af 'historiske' tendenser, som har bragt den historiske dimension tilbage til den sociologiske analyse, især analyser af staten. Og der var Kuhn, som introducerede noget af den europæiske tradition om videnskabsfilosofi og sagde ting, der la tæt op ad de temaer der udfoldes i The Craft of Sociology: Videnskab konstruerer og er selv socialt konstrueret osv. Jeg tror, at der nu er en mulighed for en modtagelse af The Craft of Sociology, hvorimod da den blev skrevet, var der intet håb; det var umuligt at se hvem i alverden, der ville være interesseret i den. Det er derfor, mens vi dengang havde en masse besvær med at finde tekster af sociologer, som illustrerede vores synspunkter, det nok ville være meget lettere i dag.

Jeg tror der har været store forandringer, især i USA. Sideløbende med den centrale ortodoxi, den der blev forsvaret af den vigtigste triade, Parsons, Robert K. Merton og Lazarsfeld, er alle former for nye tendenser udviklet. Mere kritiske - og selvkritiske - forskningsformer er dukket op (selvom man i Europa og især i Tyskland, hvor dualismen mellem teori og positivistisk empiricisme stædigt fastholdes, ikke synes at have bemærket det; hovedlandet er under forandring, men i det amerikanske kulturelle imperiums udposter er det business as usual). Når det er sagt, når kritikken af talestrategier eller af observations- og interviewstrategier bliver et mål i sig selv, fører det til en slags nihilistisk og endda mørkemandsagtig frasigelse, hvilket på alle måder er det modsatte af den indledende epistemologiske kritik fremsat i The Craft of Sociology, som sigtede mod at hjælpe til at højne sociologiens videnskabelighed.

B.K.: Der er en irrationalistisk bølge, som siger: "Alt dette er nytteløst! Hvad er videnskab, når alt kommer til alt? Bare en anden måde at tjene til livets opretholdelse!"

P.B.: Ja, og det er derfor epistemologi altid er meget vanskelig. Jeg tror ikke at nogen $\varnothing n s k e r$ at se den sociale verden, som den er. Der er mange måder at fornægte den på; en af dem er kunst, naturligvis. Men der er selv inden for sociologien en form, der har den bemærkelsesværdige egenskab, at den taler om den sociale verden, som om den ikke talte om den - formalistisk sociologi, som skærmer sig bag et sæt af ligninger, almindeligvis dårligt konstruerede, mellem forskeren og virkeligheden. Det er en anden form for nihilisme. Benægtelse, Verneinung i Sigmund Freuds betydning, er en form for verdensflugt. Hvis du ønsker at flygte fra verden, som den er, kan du blive musiker, eller filosof eller matematiker. Men hvordan kan du flygte fra den som sociolog? Nogle folk klarer det. Man skal bare skrive nogle matematiske formler, gennemgå nogle få øvelser i spilteori, en smule computer-simulering. For at være i stand til at se og beskrive verden, som den er, må man være parat til altid at have med ting at gøre, som er komplicerede, forvirrede, urene, usikre, som alle går imod den almindelige opfattelse af intellektuel stringens.

Paris, december 1988. 


\section{Referencer}

Bernhard, T. (1985). Alte Meister. Eine Komödie. Frankfurt am Main: Suhrkamp.

Blau, J. R. (1988). "Study of the Arts; A Reappraisal". Annual Review of Sociology, 14, Palo Alto, California, s. 269-292.

Bourdieu, P. (1984). Homo Academicus. Paris: Éditions de Minuit.

Bourdieu, P. (1980). Le sens Pratique. Paris: Éditions de Minuit.

Bourdieu, P. (1979). La Distinction. Critique sociale du jugement. Paris: Éditions de Minuit.

Bourdieu, P., J.-C. Chamboredon, J.-C. Passeron (1991). The Craft of Sociology. Epistemological Preliminaries. Berlin, New York: Walter de Gruyter.

Bourdieu, P. \& B. Krais (1991). "Meanwhile I have come to know all the diseases of sociological understanding". In: Bourdieu et al. (1991), s. 247-259.

Przeworski, A. \& F. Salomon, (1981): On the Art of Writing Proposals. New York: Social Research Council.

Witten M. \& R. Wuthnow (1988). "New Directions in the Study of Culture". Annual Review of Sociology, 14, Palo Alto, California, s. 49-67. 